\title{
Antimicrobial activities and mechanism of action of Cymbopogon khasianus (Munro ex Hackel) Bor essential oil
}

\author{
Gurpreet Singh $^{\dagger}$ and Meenu Katoch ${ }^{*+}$ (D)
}

\begin{abstract}
Background: Due to concerns regarding the safety of the chemical control measures, the trend is shifting globally towards the use of natural compounds as antimicrobial agent especially, plant essential oils.

Results: This study presented the antibacterial potential of Cymbopogon khasianus essential oil (CKEO) against human pathogens: Pseudomonas aeruginosa, Salmonella typhimurium, Escherichia coli, Klebsiella pneumoniae, Bacillus subtilis, Staphylococcus aureus and Candida albicans with MIC ranging from 20 to $100 \mu \mathrm{g} / \mathrm{mL}$. CKEO, in comparison to its major constituent, geraniol, showed better MICs against tested pathogens. In combination studies, the effective concentrations of CKEO and streptomycin were reduced from 20 to $5 \mu \mathrm{g} / \mathrm{mL}$ and 11 to $0.7 \mathrm{ng} / \mathrm{mL}$ against E. coli. This suggests their synergistic action. However, CKEO showed partial synergy with ciprofloxacin. To understand the efficacy of CKEO, time-kill kinetics was performed. CKEO took the half time to show the bactericidal effect in comparison to streptomycin at their 2x MICs (double the MIC), while their combination took only 30 min for this. Fluorescence and surface electron microscopic and protein estimation studies suggested the multi-target action of CKEO-streptomycin combination against E. coli. Further, CKEO alone/in combination exhibited less than $10 \%$ haemolytic activity at its MIC.
\end{abstract}

Conclusion: These results indicate that CKEO is a potentially safe alternative for the treatment of various pathogenic bacterial strains. It could be used for a variety of applications including human health, food storage, aquaculture, etc.

Keywords: Antimicrobial, Cymbopogon khasianus, Essential oil, Minimum inhibitory concentration, Streptomycin

\section{Background}

Antibiotic therapy is one of the most important therapies used for treating bacterial infections and has tremendously improved human life from the days of its introduction. But in the past few decades, the development and spread of resistant pathogenic strains threatens human health globally [1]. The most important factor for developing resistance is the excessive exposure of bacterial strains to antibiotics [2]. Consequently, it is

\footnotetext{
* Correspondence: meenusamiksha@rediffmail.com; mkatoch@iiim.ac.in ${ }^{\dagger}$ Gurpreet Singh and Meenu Katoch contributed equally to this work. Microbial Biotechnology Division, Indian Institute of Integrative Medicine, Canal Road, Jammu 180001, India
}

essential either to reduce/halt the use of antibiotics or to develop and use the alternative of antimicrobials.

In recent years, interest in medicinal plants has attracted the attention of pharmaceutical and scientific communities as sources of antimicrobial substances. In the global market, due to concerns regarding the safety of the chemical control measures, the trend is shifting towards the use of effective and nontoxic antimicrobial agents amongst natural compounds that have been previously used in cosmetics, folk medicine, and aromatherapy [3, 4].

Essential oils (EOs), biosynthesized by aromatic medicinal plants as secondary metabolites, are the oily liquids that contain a mixture of compounds [5]. They possess

C The Author(s). 2020 Open Access This article is licensed under a Creative Commons Attribution 4.0 International License, which permits use, sharing, adaptation, distribution and reproduction in any medium or format, as long as you give appropriate credit to the original author(s) and the source, provide a link to the Creative Commons licence, and indicate if changes were made. The images or other third party material in this article are included in the article's Creative Commons licence, unless indicated otherwise in a credit line to the material. If material is not included in the article's Creative Commons licence and your intended use is not permitted by statutory regulation or exceeds the permitted use, you will need to obtain permission directly from the copyright holder. To view a copy of this licence, visit http://creativecommons.org/licenses/by/4.0/. The Creative Commons Public Domain Dedication waiver (http://creativecommons.org/publicdomain/zero/1.0/) applies to the data made available in this article, unless otherwise stated in a credit line to the data. 
various bioactive properties such as antimicrobial, antiviral, antimycotic, antioxygenic, antiparasitic, antiviral, and insecticidal $[6,7]$. Initially, they were used because of their fragrance and flavour, but nowadays they are gaining popularity and widely used for a variety of purposes including household cleaning products, personal beauty care, prolonging the shelf life of food, in aquaculture and as natural medicines.

The Genus Cymbopogon (family Poaceae), is a tall densely tufted perennial grass with profuse tillering known for its medicinal use. Leaves of the plant were erect, green and linear. It is found either in wild or cultivated in tropical and semitropical areas of Asia, South and Central America, and Africa [8]. The leaves and roots of C. olivieri are widely used as antiseptic and for the treatment of stomach ailments [9]. Decoctions of the leaves and flowers of $C$. giganteus are effectively used for the treatment of migraine and diseases of skin, conjunctiva, and liver [10]. Cymbopogon essential oils have insect repellent properties for vectors of malaria, filariasis, and dengue [11]. Despite the immense commercial significance of the essential oils of the genus, little effort has been made on C. khasianus essential oil [12]. It is the right time to investigate the bioactive potential of $C$. khasianus essential oil when the demand for natural products is escalating because of its safe use with no side effects.

The aim of this research was to study the chemical profile and in vitro effect of the C. khasianus essential oil, alone and in combination with the commercial antibiotics, on the growth of pathogenic bacteria. Also, the possible mechanism of action was studied.

\section{Methods}

\section{Plant material}

C. khasianus was cultivated in the farmhouse of the Indian Institute of Integrative Medicine (IIIM, CSIR, Jammu, India) (Latitude $32^{\circ} 43^{\prime} \mathrm{N}$, Longitude $74^{\circ} 54^{\prime} \mathrm{E}$, altitude $340 \mathrm{~m}$ asl). The plant flowers twice in a year (March to April and September to October). The identification of species was made by a taxonomist (Dr. S.N. Sharma, IIIM) and its specimen was deposited in the Janaki ammal herbarium, IIIM, Jammu with voucher number 3047. The leaves of plants (randomly selected twenty plants) were collected and used directly for the isolation of essential oil.

\section{Isolation of the essential oils}

The fresh aerial parts of C. khasianus (1000 g) were subjected to hydro-distillation for $4 \mathrm{~h}$ in Clevenger type apparatus [13]. The distilled EO was dried over anhydrous sodium sulfate. The EO was stored in the dark at $4{ }^{\circ} \mathrm{C}$ until used for chemical analysis.

\section{Gas chromatography-mass spectrometry (GC/MS)}

GC/MS analysis was carried out on a Varian GC/MS 4000 coupled with gas chromatograph 3800 fitted with a Varian factor four VF-5 ms fused silica capillary column. Its dimension were $30 \mathrm{~m} \times 0.25 \mathrm{~mm}$ id, film thickness $0.25 \mu \mathrm{m}$. Temperature of the oven was set at $60{ }^{\circ} \mathrm{C}$, which was programmed to rise to $250^{\circ} \mathrm{C}$ at the rate of $5^{\circ} \mathrm{C} / \mathrm{min}$. Helium was used as carrier gas. Its flow rate was set at $1 \mathrm{~mL} / \mathrm{min}$. Mass spectra were recorded with E.I. at $70 \mathrm{eV}$. Range of mass spectra was chosen $50-300$ $\mathrm{amu}$ at the speed of one scan per second.

Initial volatile organic compounds (VOC) identification was made by comparison of obtained mass spectra of each component from CKEO with the mass spectra available in the NIST library (National Institute of Standards and Technology) database. Thus, the VOCs with $\geq 70 \%$ quality match score were presented in this report in the chemical terminology of the NIST database, while unidentified compound's area were lumped together.

The final identification of the major compounds was done on the comparative chromatographic analysis of standard samples under similar conditions as described above. However, identification of several compounds was tentative due to non availability of their standards. Each compound present in CKEO was quantified approximately on the basis of its relative peak area obtained after GC/MS analysis. The GC/MS analyses were performed three times and mean values of relative peak areas were presented.

\section{Microorganisms}

The antimicrobial assay was evaluated against human pathogens procured from Microbial Type Culture Collection, Chandigarh. The study includes both Gram-negative E. coli MTCC 118, K. pneumoniae MTCC 109, P. aeruginosa MTCC 424, S. typhimurium MTCC 98 and Gram-positive B. subtilis MTCC 121, S. aureus MTCC 737 bacteria and a yeast pathogen $C$. albicans MTCC 183. All the cultures were grown on nutrient agar media, while yeast extract peptone dextrose (YEPD) agar was used for C. albicans.

\section{Antimicrobial assay}

The antimicrobial activity of the EOs was determined using the microdilution assay method [14, 15]. Briefly, each bacterial culture was aseptically inoculated in nutrient broth (HiMedia Biosciences) and grown overnight at $37^{\circ} \mathrm{C}$ with shaking $(200 \mathrm{rpm})$. The suspension was diluted to $1.5 \times 10^{8}$ colony forming units (CFU/ mL) equivalent to 0.5 McFarland standard turbidity based on optical density (0.132) at the wavelength of $600 \mathrm{~nm}$ and finally adjusted to give approximately $1.5 \times 10^{5}$ cells $/ \mathrm{mL}$ for each organism. Fresh stock solution of CKEO (10 $\mathrm{mg} / \mathrm{mL}$ ) was prepared using DMSO. Different dilutions $(10-100 \mu \mathrm{g} / \mathrm{mL})$ were prepared from the stock solution of CKEO and different antibiotics $(1 \mathrm{mg} / \mathrm{mL}$ in sterile 
distilled water). Antibiotics such as streptomycin, amphotericin B were used as positive controls. Different dilutions of CKEO and antibiotics $(150 \mu \mathrm{L})$ were mixed with the nutrient broth containing $4 \times 10^{4} \mathrm{CFU}$ bacteria $(50 \mu \mathrm{L})$. Appropriate negative (1\% DMSO) and blank controls (un-inoculated media) were used. Microtiter plates (96 wells) were incubated at $37^{\circ} \mathrm{C}$ for $12-16 \mathrm{~h}$. The concentration, which killed $99.9 \%$ of the pathogen, was considered as the minimum bactericidal concentration $(\mathrm{MBC})$, while the concentration, preventing the visible growth of bacteria under defined growth conditions, was considered as the minimum inhibitory concentration (MIC) [16]. MBCs were determined by plating $50 \mu \mathrm{L}$ of the treated mix (without dilution) of the wells showing no colonies on nutrient agar.

\section{Assessing synergistic interaction between the essential oil, and different antibiotics (streptomycin, ciprofloxacin)} The combined effect of EO and conventional antibiotics (streptomycin, ciprofloxacin) on antimicrobial activity has been studied by the checkerboard microdilution test as described by [17] with few modifications. This assay was performed in a 96-well plate using two-fold serial dilutions. Conventional antibiotics were diluted vertically, whereas EO was diluted horizontally so that each well should contain different concentrations of two compounds. The starting concentration of each compound was the MIC. Following this, $50 \mu \mathrm{L}$ suspension containing $4 \times 10^{4}$ cells of test bacteria was pippetted to each well. The plates were incubated at $37^{\circ} \mathrm{C}$ for $24 \mathrm{~h}$ and visually inspected for growth [16]. The lowest concentration of combination (EOs and antibiotics), which did not contain any visually detectable bacterial growth was considered as MIC. Besides, the control (containing test bacteria but no EOs/antibiotics) was used to assess the growth of bacteria, while the negative control was taken to assess the clarity/turbidity in the CKEO/combination. Each test was performed in replicates. The checkerboard generates many effective combinations (the first clear well of each row of the microtiter plate containing antimicrobial agents), and the fractional inhibitory concentration index (FICI) was calculated [18].

$$
\begin{aligned}
\mathrm{FICI} & =\mathrm{FIC}_{\mathrm{CKEO}}+\mathrm{FIC}_{\text {antibiotic }} \\
& =\mathrm{C}_{\mathrm{CKEO}} / \mathrm{MIC} \mathrm{CKKO}_{\mathrm{CKO}}+\mathrm{C}_{\text {antibiotic }} / \mathrm{MIC}_{\text {antibiotic }}
\end{aligned}
$$

Where $\mathrm{MIC}_{\mathrm{CKEO}}$ and $\mathrm{MIC}_{\text {antibiotic }}$ are MICs of CKEO and antibiotic when used alone; $\mathrm{C}_{\mathrm{CKEO}}$ and $\mathrm{C}_{\text {antibiotic }}$ are MICs of CKEO and antibiotic at their isoeffective combination respectively. FICI was interpreted as follows: FICI $<0.5$, synergistic, FICI of $\geq 0.5$ and $<1$ partial synergy; FICI of 1 additive; FICI $>4$ antagonistic.

\section{Time kill kinetics}

E. coli cells were grown to mid logarithmic phase. They were diluted as described above in antimicrobial assay. The diluted bacterial suspension $\left(10^{4} \mathrm{CFU}\right)$ was incubated with 1/2MIC, MIC and 2MIC concentration of oil/streptomycin or with 2FICI and 3FICI concentrations of their combination for different time period namely 10, 30, 60 and $120 \mathrm{~min}$ respectively. Post incubation, the cells were diluted by $10^{2}$ times and $50 \mu \mathrm{L}$ suspension was spread on nutrient agar plates. Plates were incubated at $37^{\circ} \mathrm{C}$ for $24 \mathrm{~h}$ and the colonies appeared on them were counted [15].

\section{Scanning electron microscopy (SEM)}

Scanning electron microscopic studies were conducted to observe the changes in morphology of bacterial cells treated with antimicrobial agents [19]. E. coli cells were treated with streptomycin/EO/combination at their $2 \mathrm{xMICs}$ for $2-3 \mathrm{~h}$. Then, treated cells were centrifuged and washed with sterile PBS solution. They were fixed with $2.5 \%$ glutaraldehyde in phosphate buffer ( $\mathrm{pH} 7.4)$ for $24 \mathrm{~h}$ at $4{ }^{\circ} \mathrm{C}$ followed by washing and second fixation was done with $1 \%$ osmium tetraoxide for $6-7 \mathrm{~h}$ at $4{ }^{\circ} \mathrm{C}$. Post fixations, dehydration of samples were done sequentially in ethanol of different concentrations (30, 50, 70 , and $100 \%$ ) for $30 \mathrm{~min}$ each. The drying of samples was achieved through hexamethyl disilazane/ethanol gradient series (50:50 and 100:0) for $30 \mathrm{~min}$ at each concentration. Finally, the samples were mounted on aluminium stubs and sputter-coated with gold, prior to inspection under microscope (JOEL JSM-6400, Japan).

\section{Fluorescence microscopy}

To assess the effect of EO/antibiotic alone and in combination on bacterial membrane integrity, the double dye staining method was employed using DAPI (4', 6 diamidino-2-phenylindole dihydrochlorides) and PI (propidium iodide) [15]. DAPI is a cell-permeable dye, which binds with A-T base pairs of double-stranded DNA and allows for powerful fluorescence signals, whereas PI is cell impermeable and only penetrates dead cells. The E. coli cells were grown up to mid-logarithmic phase and treated with streptomycin/EO alone and in their combination (at the $2 \mathrm{x}$-MIC concentration) for $2 \mathrm{~h}$ at $37^{\circ} \mathrm{C}$. They were centrifuged at $5000 \mathrm{~g}$ for $15 \mathrm{~min}$ and the supernatant was removed. Pelleted cells were washed with sterile PBS solution then incubated with DAPI $(10 \mu \mathrm{g} / \mathrm{mL})$ and PI $(5 \mu \mathrm{g} /$ $\mathrm{mL}$ ) respectively for $15-15 \mathrm{~min}$ at $0^{\circ} \mathrm{C}$ in dark. After the dye treatment, cells were washed with phosphate buffer to remove excess stain. The cells without any antimicrobial agents were designated as control. Treated cells were observed under inverted microscope and their images were captured with the attached digital camera (Olympus Imaging Corp., Centre Valley, PA, USA). 


\section{Protein estimation}

Bacterial cells were grown up to mid-logarithmic phase as described above in antimicrobial assay and treated with MIC values of test compounds (CKEO/streptomycin alone and their combination). After the treatment of E. coli, the protein content in the extracellular medium was examined through colorimetric assay using a BCA protein assay kit (Thermo Scientific) as per the manufacturer's instructions. The 96 well plate was kept in BOD set at $37^{\circ} \mathrm{C}$ for $30 \mathrm{~min}$, and absorbance was checked at $562 \mathrm{~nm}$ using a microtiter plate reader. The standard calibration curve was prepared using the bovine serum albumin (BSA) protein solutions $(0-2 \mathrm{mg} / \mathrm{mL}$ ) and used for calculating the protein content present in bacterial cell-extracellular medium with and without exposure of test compounds.

\section{The haemolytic activity}

The haemolytic activity of CKEO, streptomycin alone and in combination was determined by using human red blood cells (RBCs) (blood used in the current study belongs to an author and was collected by the trained technician working in the dispensary of the Institute on his request) [20]. Fresh human RBCs were separated after centrifugation and rinsed thrice with sterile Phosphate buffer solution (PBS pH 7.4). The RBCs pellet was re-suspended in PBS solution to obtain a $5 \%$ solution. RBCs suspension $(50 \mu \mathrm{L})$ was added to 96 -well plate containing $150 \mu \mathrm{L}$ of different concentrations of samples. The plate was incubated for $30 \mathrm{~min}$ at room temperature and was centrifuged at $2000 \mathrm{rpm}$ for $20 \mathrm{~min}$. The supernatant $(100 \mu \mathrm{L})$ was transferred to a fresh 96-well plate and optical density (OD) was recorded at $360 \mathrm{~nm}$ wavelength. Triton X$100(0.1 \%)$ was used as a positive control. The haemolysis was calculated in percent using a formula (sample abs -PBS abs)/ triton X abs- PBS abs)*100 [15]. The experiment was done in triplicate.

\section{Result and discussion}

The essential oil analysis

The GC/MS analysis of the CKEO from the leaves of plants collected from the north-western region of India showed 26 components representing $98.25 \%$ of the EO with geraniol $(81.74 \%)$, geranyl acetate $(5.39 \%)$, cis- $\beta$ ocimene (3.02\%), linalool (1.27\%) and trans- $\beta$-ocimene (1.25\%). (Table S1, Fig. S1). Choudhury and Leclercq [21] reported the same components in the CKEO from the leaves of plants with little variation in the percentage of geraniol (78.4\%), geranyl acetate (7.3\%), and linalool (2.2\%) from the plants collected from the north-eastern region of India. The variation in the components of EO could be due to different eco-geographical regions. Some reports suggested that different varieties of C. khasianus collected/selected from north-eastern region of India contained different major compounds such as methyl eugenol/elemicin/geraniol in their EOs [22-24]. Recently, a study revealed that part of the plant (inflorescence/leaves) used for extraction of EO affects the yield of essential oil (0.82/0.70\%), but not its components [12]. Similar to the current study, geraniol was found 18.81 and $22.78 \%$, as the major component in the EO of C. winterianus collected from Brazil and Germany, respectively $[25,26]$. C. nardus from Thailand contained geraniol (35.7\%) as its major constituent, while C. nardus from Malaysia did not contain geraniol [27, 28]. Hence, in the recent past, a widest adaptable and stable variety (CIMAP Suwarna) of C. khasianus was chosen using AMMI (additive main effects and multiplicative interactions) model [29].

\section{Determination of the antimicrobial activity of CKEO oil by microdilution method}

The antimicrobial activities of CKEO and geraniol were examined against various pathogens using microdilution assay. Results in terms of both the minimum inhibitory concentrations (MIC) and minimum bactericidal concentrations $(\mathrm{MBC})$ are given in Table 1. CKEO inhibited the

Table 1 Minimal inhibitory/bactericidal concentration (MIC/MBC in $\mu \mathrm{g} / \mathrm{mL}$ ) of C. khasianus essential oil (CKEO) essential oil and streptomycin

\begin{tabular}{|c|c|c|c|c|c|}
\hline \multirow[t]{2}{*}{ Pathogen } & \multicolumn{2}{|c|}{ CKEO } & \multicolumn{2}{|c|}{ Streptomycin/Amphotericin B } & \multirow{2}{*}{$\begin{array}{l}\text { Geraniol } \\
\text { MIC }\end{array}$} \\
\hline & MIC & MBC & MIC & MBC & \\
\hline E. coli & 20 & 20 & 0.011 & 0.3125 & $>100$ \\
\hline S. aureus & 30 & - & - & 0.3125 & $>100$ \\
\hline P. aeruginosa & 20 & 30 & - & 0.3125 & $>100$ \\
\hline S. enterica typhimurium & 30 & - & - & 0.3125 & $>100$ \\
\hline B. subtilis & 25 & - & - & 0.3125 & $>100$ \\
\hline K. pneumoniae & 20 & - & - & 0.3125 & $>100$ \\
\hline C. albicans & 100 & - & - & 6.25 & $>100$ \\
\hline
\end{tabular}


Table 2 Minimal inhibitory concentration (MIC) of C. khasianus essential oil (CKEO) and streptomycin alone and in combinations against E. coli

\begin{tabular}{lllllll}
\hline Strain & MIC (alone) & $\begin{array}{l}\text { MIC }(\mu \mathrm{g} / \mathbf{m L}) \\
\text { combination }\end{array}$ & Fold reduction & $\begin{array}{l}\text { Fractional inhibitory } \\
\text { concentration index (FICl) }\end{array}$ & Result \\
\hline E. coli & Streptomycin & 0.011 & 0.0007 & 16 & 0.316 & Synergy \\
& CKEO & 20 & 5 & 4 & 0.531 & Partial Synergy \\
& Ciprofloxacin & 0.1875 & 0.0937 & 2 & & \\
& CKEO & 20 & 0.625 & 32 & & \\
\hline
\end{tabular}

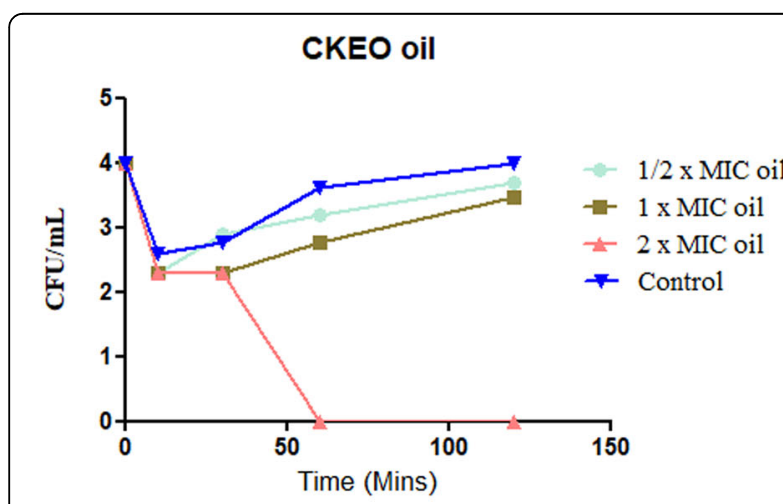

Streptomycin
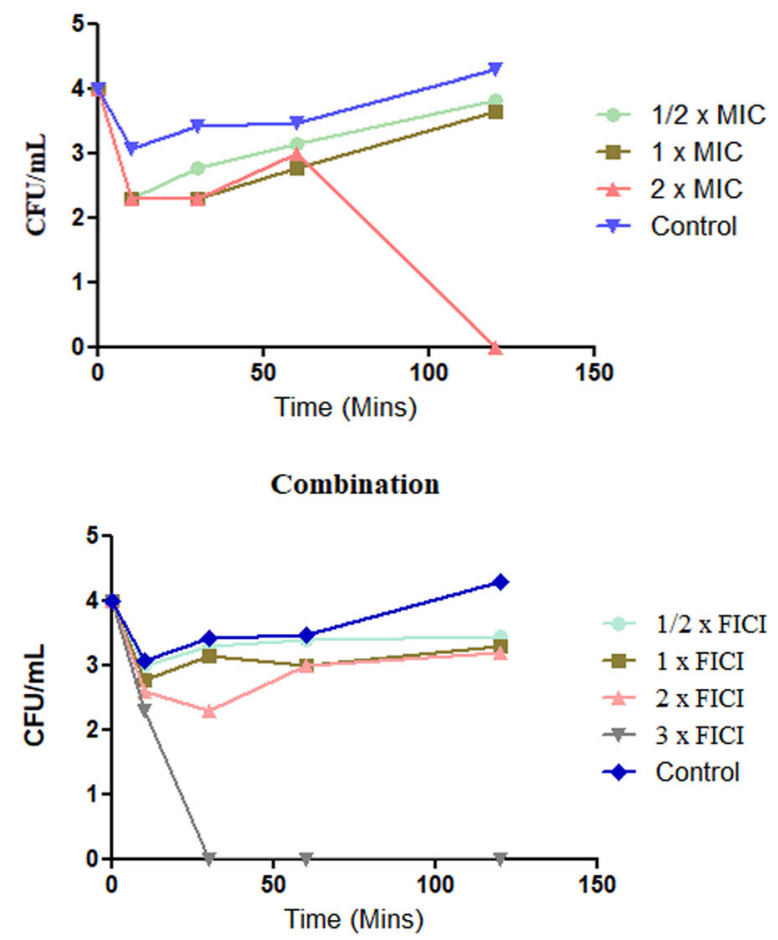

Fig. 1 Time-kill curves of CKEO, streptomycin and their combination against E. coli. The count of dead cells was monitored for the first 2 h. Colour of lines indicates the concentration of the treatment used in the experiment blue untreated control, sea green 1/2 MIC/FICl, green $1 \times \mathrm{MIC} / \mathrm{FICl}$, pink 2x MIC/FICl, grey 3xMIC/FICl growth of E. coli with MIC and MBC $20 \mu \mathrm{g} / \mathrm{mL}$. It has also inhibited the growth of B. subtilis, S. enterica typhimurium, S. aureus, K. pneumoniae with MICs $25-50 \mu \mathrm{g} / \mathrm{mL}$. The CKEO was also found active against $C$. albicans and inhibited the growth with MIC $100 \mu \mathrm{g} / \mathrm{mL}$. These results suggested that CKEO had broad-spectrum antimicrobial activity against both Gram-positive and Gram-negative bacteria.

E. coli was found to be highly susceptible to CKEO with $\mathrm{MBC}$ of $20 \mu \mathrm{g} / \mathrm{mL}$. The essential oil from C. nardus inhibited the growth of $E$. coli at much lower MIC $(0.488 \mu \mathrm{g} / \mathrm{mL})$ [28]. Bassole et al. [10] reported antimicrobial activity of $\mathrm{EO}$ of C. citratus and C. giganteus. Their MICs ranged between $2.1-80 \mathrm{mg} / \mathrm{mL}$ against $S$. aureus, E. coli, P. aeruginosa, and S. typhimurium. Adinarayana et al. [30] also observed growth inhibition of $S$. aureus and B. subtilis with the use C. flexuosus $\mathrm{EO}$ at a MIC of $250.5 \mu \mathrm{g} / \mathrm{mL}$ and $257.3 \mu \mathrm{g} / \mathrm{mL}$ respectively. Against E. coli, he reported MIC $294.5 \mu \mathrm{g} / \mathrm{mL}$, which was higher than the present study. Sonboli et al. [31], reported the antimicrobial activity of the essential oil of $C$. oliveri with MIC of $3.75 \mathrm{mg} / \mathrm{mL}$ and $2.5 \mathrm{mg} / \mathrm{mL}$ against B. subtilis and C. albicans, respectively. Results suggested a high variation in antimicrobial activity of different species of the same genus might be due to the change in oil composition of the same/different species belonging to the different eco-geographical regions.

To understand the role of geraniol, a major constituent in CKEO, in antimicrobial activity, we compared the antibacterial activity of CKEO and geraniol against different pathogens. MICs of CKEO for all tested organisms were found to be lower than the MICs of geraniol. The MICs of geraniol in literature ranged between $0.5-$ $1.4 \mathrm{mg} / \mathrm{mL}$ against different pathogens, which support the result of the present study [32-36]. Thus, it can be concluded that geraniol is not the sole responsible constituent for antimicrobial activity; other components such as geranyl acetate, linalool and $\beta$-ocimene are also involved in it [37-39]. In the contrary, methyl eugenol alone was found more effective against the microbes in comparison to methyl eugenol rich CKEO [40].

\section{Synergistic interactions between the essential oil and antibiotics} Due to the non-availability of new antibiotics into the market and an increase in antibiotic-resistant pathogenic 

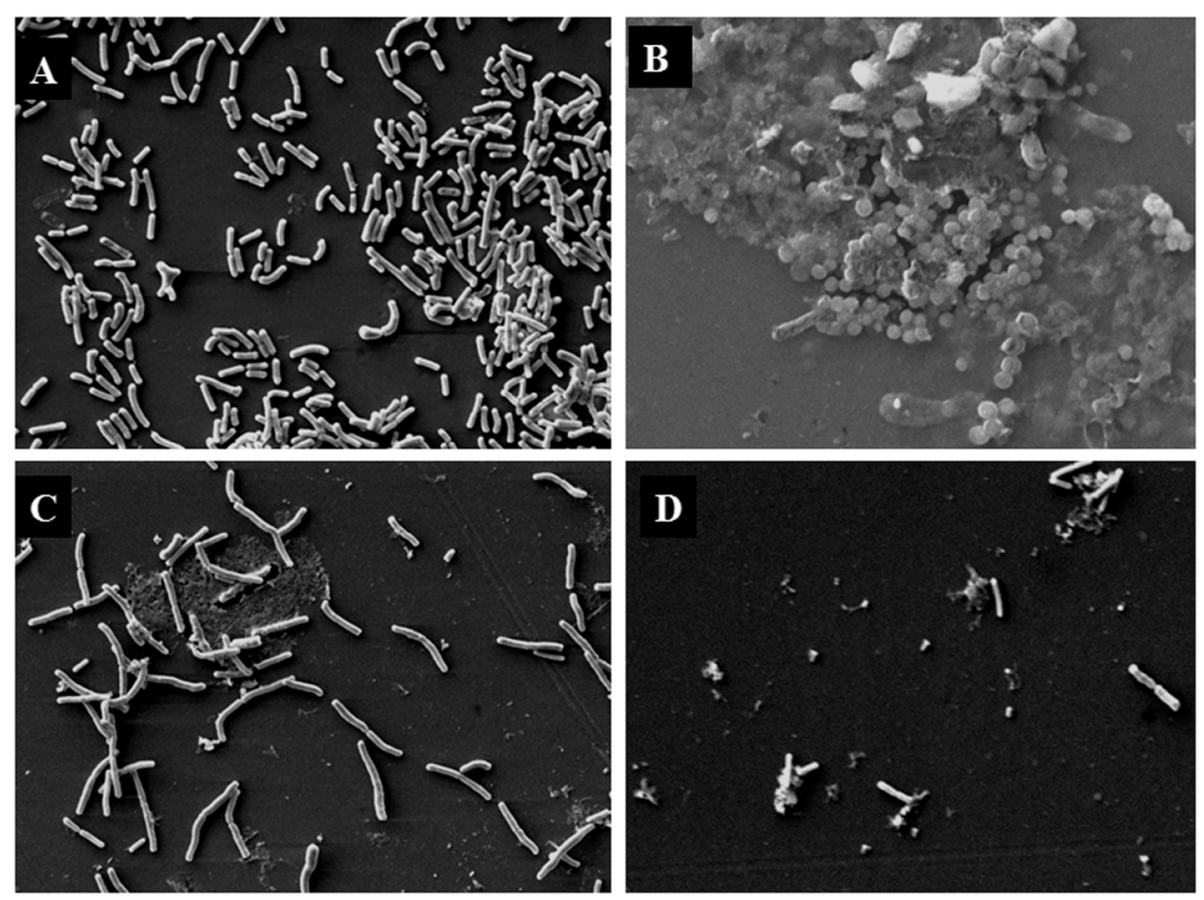

Fig. 2 Scanning electron micrographs of E. coli (a) untreated cells (b) CKEO treated cells (c) streptomycin treated cells (d) CKEO plus streptomycin treated cells

bacteria, alternative strategies are needed to cope up with the rising threat. In this study, the combined effect of CKEO with conventional antibiotics against E. coli was investigated by the checkerboard method, and the FIC and the FICI were calculated to determine the interaction of the CKEO with streptomycin/ciprofloxacin.

The CKEO showed total synergy in combination with streptomycin with FIC 0.316. However, its combination with ciprofloxacin showed partial synergy with FICI of 0.531 .

Essential oils are a multi-component mixture with multiple target sites, due to which there is an increase in combination studies with conventional antimicrobial agents to treat infectious bacterial pathogens [41, 42]. Indeed, the combination of tested CKEO with streptomycin had shown significant results. The combination allowed a decrease in streptomycin concentration by 16 times, while there were four times decrease in the essential oil concentration (Table 2). However, in the combination, effective concentrations of ciprofloxacin and CKEO were reduced by two and thirty-two fold respectively.

To understand the efficacy of CKEO and streptomycin alone and in combination, the time-kill assay was performed and the viable cell number in terms of CFU was calculated. The treatment with CKEO/ streptomycin led to a dose-dependent response in terms of $E$. coli cell number (Fig. 1). At 2xMIC value, $\mathrm{CKEO} /$ streptomycin had totally eradicated the pathogen. At 2xFICI value, the combination of CKEO and streptomycin was found bacteriostatic but at 3xFICI value, pathogenic cells were completely eradicated within $30 \mathrm{~min}$ of exposure.

\section{Scanning electron microscopy studies}

The change in surface morphology of $E$. coli when treated at MIC concentrations of streptomycin $(0.011 \mu \mathrm{g} / \mathrm{mL})$, CKEO $(20 \mu \mathrm{g} / \mathrm{mL})$ and in the combination of streptomycin $(7 \mathrm{ng} / \mathrm{mL})$ plus CKEO $(5 \mu \mathrm{g} / \mathrm{mL})$ were examined. The control cells (when grown in the absence of any oil and streptomycin) under scanning electron microscope were found normal rod shaped structures with a smooth surface (Fig. 2). When treated with CKEO alone, small shrunken circular cells with wrinkled surface were observed, whereas with streptomycin treatment, cells became elongated. Cells treated with their combination had shown membrane shrinkage and destruction.

\section{Fluorescence microscopy}

To study the effect of antibacterial agents on bacterial membrane integrity, fluorescence microscopy was employed [43]. As shown in Fig. 3, all bacterial cells in control were blue, whereas the treatment of cells with CKEO and their combination led both red and blue bacterial cells, suggesting it is a consequence of an impairment of membrane integrity. Hence the possible target of the CKEO is the bacterial membrane. Similarly, Zhang et al. [44] found that cinnamon oil altered the integrity and permeability of $E$. coil and S. aureus cells, while 


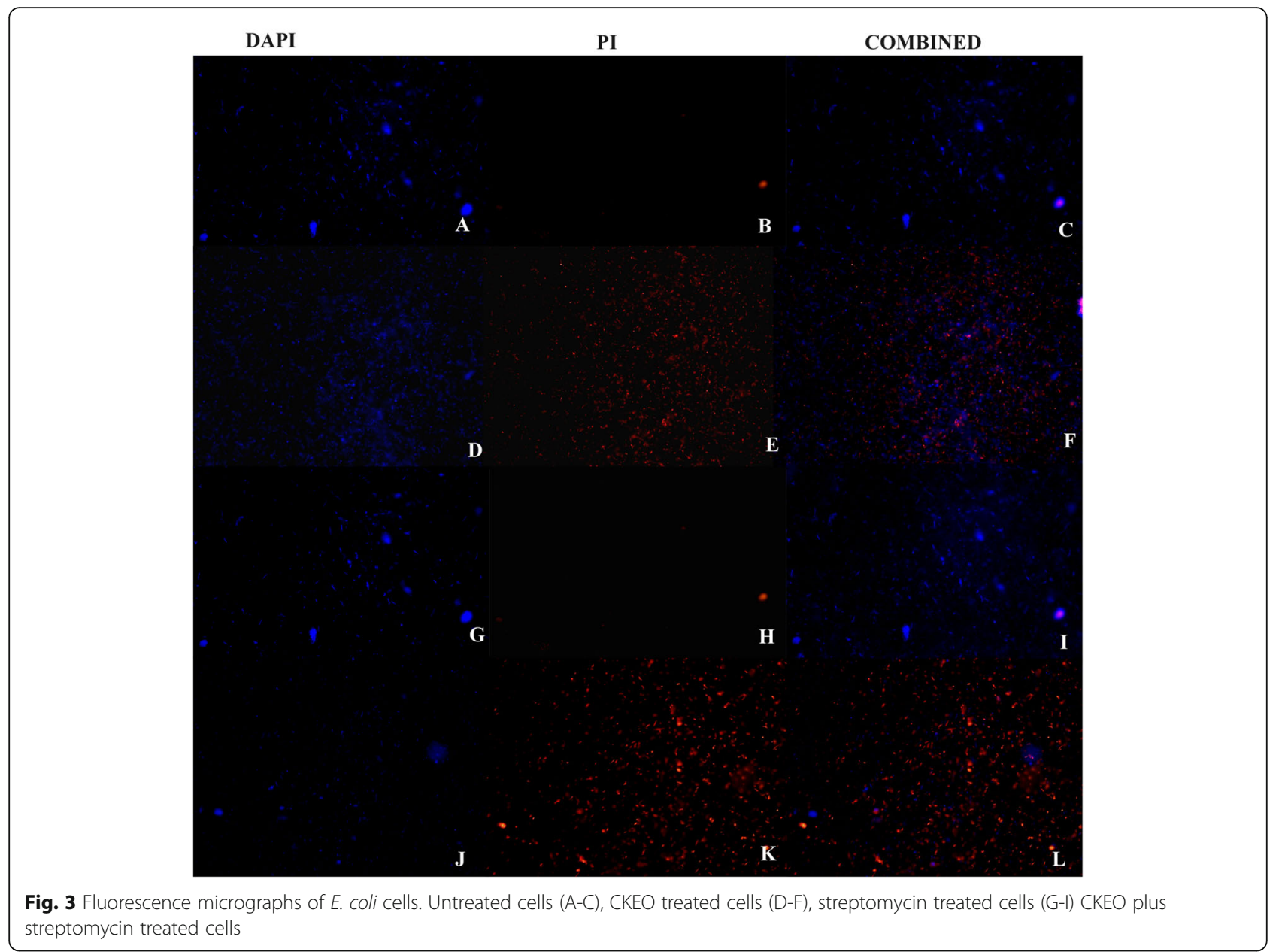

Heydari et al. [45] found that Mentha piperita and $M$. arvensis oils targeted the integrity of Bacillus cereus cell membrane. However, bacterial cells treated with streptomycin had shown only the blue signal (DAPI), which suggested that streptomycin does not compromise membrane integrity/permeability.

\section{Protein content analysis}

Protein content in the extracellular medium of untreated and treated E. coli cells was analyzed to understand the mechanism of CKEO, streptomycin, and their combination (Table 3). The analysis revealed the highest protein content in untreated E. coli cells. Dalbey and Kuhn [46] reported that many proteins, which got assembled into the inner and outer membranes of gramnegative bacteria, were exported to the periplasm or the extracellular medium. Cells treated with streptomycin showed $46 \%$ less protein. This might be because of many reasons: firstly the number of live cells in the treated sample would be significantly less than control. Secondly, the cell membrane of the dead cell is not damaged, which was already confirmed by florescent microscopy. Cells treated with CKEO showed more

Table 3 Protein Content analysis in extracellular medium of treated E. coli cells ( $\mathrm{mg} / \mathrm{mL}$ )

\begin{tabular}{llll}
\hline Treatment & $\begin{array}{l}\text { Minimum Inhibitory } \\
\text { Concentration }(\boldsymbol{\mu} \mathbf{g} / \mathbf{m L})\end{array}$ & $\begin{array}{l}\text { Protein Content in extracellular } \\
\text { medium of treated } E \text {. coli cells }(\mathbf{m g} / \mathbf{m L})\end{array}$ & $\begin{array}{l}\text { \% protein inhibition in } \\
\text { extracellular medium }\end{array}$ \\
\hline Control & - & 62.25 & - \\
Streptomycin & 0.011 & 33.58 & 46.05 \\
CKEO & 20 & 45.46 & 26.97 \\
Streptomycin + CKEO & $0.0007+5$ & 43.46 & 30.18 \\
\hline
\end{tabular}

CKEO C. khasianus essential oil 
protein $(20 \%)$ in comparison to streptomycin treated cells. As florescent microscopy study depicted that CKEO damages membrane integrity, which caused the release of proteins to present inside the cells. In the combination studies, (when E. coli cells were treated with one-fourth of CKEO and fifteen times less streptomycin) the protein content in the extracellular medium was found less in comparison to cells treated alone with CKEO, but more in comparison to cells treated alone with streptomycin. This protein content variation can be explained with results that streptomycin is not targeting cell membrane and inhibiting protein synthesis, which is a well-known fact. Hence, it might be involved in this interaction as well. Therefore, CKEO and streptomycin against $E$. coli acted in synergy but on multi-targets. Similar to our results, tea tree oil along with tobramycin, an aminoglycoside showed a synergistic effect against $E$. coli and S. aureus [47]. This was also an example of multi-target synergy.

Further, CKEO, streptomycin and its combination exhibited less than $10 \%$ haemolytic activity at its MIC/FICI value, which suggested that it could be safe for humans (Table S2). Although, there is a trend of natural products, which are believed to be safer, still before use, in vivo studies and its toxicity related studies are to be conducted.

\section{Conclusion}

These findings demonstrated that the essential oil obtained from C. khasianus is a potential alternative for the treatment of various pathogenic bacterial strains and its combination with streptomycin had synergistic interaction against $E$. coli, which can reduce the effective dose of streptomycin and CKEO both. Hence, in the future after properly addressing toxicity and safety-related issues, CKEO or its combination can be used in human health.

\section{Supplementary information}

Supplementary information accompanies this paper at https://doi.org/10 1186/s12906-020-03112-1.

Additional file 1: Table S1. Chemical composition of essential oil of C. khasianus (Munro ex Hackel) Bor. Figure S1. GC-MS chromatogram of essential oil of C. khasianus (Munro ex Hackel) Bor. Table S2. Haemolytic activity of CKEO, Streptomycin and their combination at different concentration

\footnotetext{
Abbreviations

MIC: Minimum inhibitory concentration; MBC: Minimum bactericidal concentrations; CKEO: Cymbopogon khasianus essential oil; GC/MS: Gas Chromatography-Mass Spectrometry; VOC: Volatile organic compounds; NIST: National Institute of Standards and Technology; DMSO: Di-methyl sulfoxide; CFU: Colony forming unit; FICl: Fractional inhibitory concentration index; DAPI: 4', 6 diamidino-2-phenylindole dihydrochlorides; PI: Propidium iodide; PBS: Phosphate buffer saline; RBCs: Red blood cells
}

\section{Acknowledgements}

Authors thankfully acknowledge the Council of Scientific and Industrial Research (CSIR) for proving the research platform and Dr. S. Chandra for providing CKEO. The Institutional Publication ID of the article is IIIM/IPR/ 00220

Authors' contributions

The authors read and approved the final manuscript.

\section{Funding}

MK acknowledges the aroma mission project (HCP0007) from CSIR, Government of India for financial assistance, while GS acknowledges the ICMR for the SRF-ship (ISRM/11(76)/2017).

\section{Availability of data and materials}

Most of the data generated or analysed during this study are included in this published article and its supplementary file. The rest of raw datasets of bioactivity used and/or analyzed during the current study can be available from the corresponding author on reasonable request.

Ethics approval and consent to participate

Not applicable.

Consent for publication

Not applicable.

\section{Competing interests}

The authors declare that they have no competing interests.

Received: 14 January 2020 Accepted: 8 October 2020

Published online: 05 November 2020

References

1. Langeveld WT, Veldhuizen EJ, Burt SA. Synergy between essential oil components and antibiotics: a review. Crit Rev Microbiol. 2014;40:76-94.

2. Santos $L$, Ramos F. Antimicrobial resistance in aquacultur: current knowledge and alternatives to tackle the problem. Int J Antimicrob Agents. 2018;52:135-43.

3. Ballester-Costa C, Sendra E, Fernández-López J, Pérez-Álvarez JA, ViudaMartos M. Chemical composition and in vitro antibacterial properties of essential oils of four Thymus species from organic growth. Ind Crop Prod. 2013;50:304-11.

4. Saeed F, Afzaal M, Tufail T, Ahmad A. Use of natural antimicrobial agents: a safe preservation approach. In: Var I, Uzunlu S, editors. Active antimirobial food packaging. Intech open; 2019. p. 7-24.

5. Sultanbawa Y. Plant antimicrobials in food applications: Minireview. In: Méndez-Vilas A, editor. Science against microbial pathogens: communicating current research and technological advances; 2011. p. 1084-93.

6. Molyneux RJ, Lee ST, Gardner DR, Panter KE, James LF. Phytochemicals: the good, the bad and the ugly? Phytochemistry. 2007;68:2973-85.

7. Alves-Silva JM, dos Santos SMD, Pintado ME, Pérez-Álvarez JA, FernándezLópez J, Viuda-Martos M. Chemical composition and in vitro antimicrobial, antifungal and antioxidant properties of essential oils obtained from some herbs widely used in Portugal. Food Control. 2013;32:371-8.

8. Shah G, Shri R, Panchal V, Sharma N, Singh B, Mann A. Scientific basis for the therapeutic use of Cymbopogon citratus, stapf (lemon grass). J Adv Pharm Technol Res. 2011:2:3-8.

9. Zargari A. Medicinal plants, vol. 4. Tehran: Tehran University Publications; 1991.

10. Bassolé IHN, Lamien-Meda A, Bayala BOLC, Obame LC, Ilboudo AJ, Franz C, et al. Chemical composition and antimicrobial activity of Cymbopogon citratus and Cymbopogon giganteus essential oils alone and in combination. Phytomedicine. 2011;18:1070-4.

11. Tyagi B, Shahi A, Kaul B. Evaluation of repellent activities of Cymbopogon essential oils against mosquito vectors of malaria, filariasis and dengue fever in India. Phytomedicine. 1998;5:324-9.

12. Dutta S, Munda S, Devi N, Lal M. Compositional variability in leaves and inflorescence essential oils of C khasianus (hack) Stapf ex Bor collected from Meghalaya: a biodiversity hotspot. J Essent Oil Bear PI. 2018;21:640-57. 
13. Memarzadeh SM, Pirbalouti AG, AdibNejad M. Chemical composition and yield of essential oils from Bakhtiari savory (Satureja bachtiarica Bunge.) under different extraction methods. Ind Crop Prod. 2015;76:809-16.

14. Singh G, Katoch A, Razak M, Kitchlu S, Goswami A, Katoch M. Bioactive and biocontrol potential of endophytic fungi associated with Brugmansia aurea Lagerh. FEMS Microbiol Lett. 2017;364:fnx194.

15. Wani NA, Singh G, Shankar S, Sharma A, Katoch M, Rai R. Short hybrid peptides incorporating $\beta$-and $\gamma$-amino acids as antimicrobial agents. Peptides. 2017:97:46-53.

16. Rončević T, Vukičević D, llić N, Krce L, Gajski G, Tonkić M, et al. Antibacterial activity affected by the conformational flexibility in glycine-lysine based ahelical antimicrobial peptides. J Med Chem. 2018;61:2924-36.

17. Dra LA, Brahim MAS, Boualy B, Aghraz A, Barakate M, Oubaassine S, et al. Chemical composition, antioxidant and evidence antimicrobial synergistic effects of Periploca laevigata essential oil with conventional antibiotics. Ind Crop Prod. 2017;109:746-52.

18. Odds FC. Synergy, antagonism, and what the chequer board puts between them. J Antimicrob Chemother. 2003;52:1.

19. Lv F, Liang H, Yuan Q, Li C. In vitro antimicrobial effects and mechanism of action of selected plant essential oil combinations against four food-related microorganisms. Food Res Int. 2011;44:3057-64.

20. Conlon JM, Sonnevend A, Patel M, Camasamudram V, Nowotny N, Zilahi E, et al. A melittin-related peptide from the skin of the Japanese frog, Rana tagoi, with antimicrobial and cytolytic properties. Biochem Biophys Res Commun. 2003;306:496-500.

21. Choudhury S, Leclercq PA. Essential oil of Cymbopogon khasianus (Munro ex hack.) Bor from northeastern India. J Essent Oil Res. 1995;7:555-6.

22. Rabha LC, Hazarika AK, Bordoloi DN. Cymbopogon khasianus a new rich source of methyl eugenol. Indian Perfum. 1986;30:339-44.

23. Lal M, Dutta S, Munda S, Pandey SK. Novel high value elemicin-rich germplasm of lemon grass Cymbopogon khasianus (hack) Stapf (ex Bor) from north East India. Ind Crop Prod. 2018;115:98-103.

24. Lal M, Borah A, Pandey SK. Identification of a new high Geraniol rich variety "jor lab L-15" of lemongrass [Cymbopogon khasianus (hack) Stapf (ex Bor)]. J Essent Oil Bearing Plants. 2019;22:972-8.

25. Simic A, Rancic A, Sokovic M, Ristic M, Grujic-Jovanovic S, Vukojevic J, et al, Essential oil composition of Cymbopogon winterianus and Carum carvi and their antimicrobial activities. Pharm Biol. 2008;46:437-41.

26. Oliveira WAD, Pereira FO, Luna GC, Lima IO, Wanderley PA, Lima RB, et al. Antifungal activity of Cymbopogon winterianus Jowitt ex Bor against Candida albicans. Braz J Microbiol. 2011;42:433-41.

27. Nakahara K, Alzoreky NS, Yoshihashi T, Nguyen HT, Trakoontivakorn G. Chemical composition and antifungal activity of essential oil from Cymbopogon nardus (citronella grass). Jpn Agric Res Q. 2013;37:249-52.

28. Wei LS, Wee W. Chemical composition and antimicrobial activity of Cymbopogon nardus citronella essential oil against systemic bacteria of aquatic animals. Iran J Microbiol. 2013;5:147-52.

29. Lal M. Stability for oil yield and variety recommendations using AMMI (additive main effects and multiplicative interactions) model in lemongrass (Cymbopogon species). Ind Crop Prod. 2012;40:296-301.

30. Adinarayana G, Rahul G, Kiran RS, Syamsundar KV, Rajeswara BR. Evaluation of antimicrobial potential of field distilled and water-soluble essential oils of Cymbopogon flexuosus. J Pharmacogn. 2012;3:142-6.

31. Sonboli A, Mirjalili MH, Yousefzadi M. Antimicrobial activity and composition of the essential oil of Cymbopogon Olivieri (Boiss.). Bor from Iran Iran J Pharm Res. 2010;1:65-8.

32. Kalemba D, Kunicka A. Antibacterial and antifungal properties of essential oils. Curr Med Chem. 2003;10:813-29.

33. Tampieri MP, Galuppi R, Macchioni F, Carelle M, Falcioni L, Cioni P, et al. The inhibition of Candida albicans by selected essential oils and their major components. Mycopathologia. 2005;159:339-45.

34. Si W, Gong J, Tsao R, Zhou T, Yu H, Poppe C, et al. Antimicrobial activity of essential oils and structurally related synthetic food additives towards selected pathogenic and beneficial gut bacteria. J Appl Microbiol. 2006;100:296-305.

35. Van Zyl RL, Seatlholo ST, Van Vuuren SF. The biological activities of 20 nature identical essential oil constituents. J Essent Oil Res. 2006;18:129-33.

36. Rosato A, Vitali C, Laurentis N, Armenise D, Antonietta MM. Antibacterial effect of some essential oils administered alone or in combination with Norfloxacin. Phytomedicine. 2007;14:727-32.

37. Gochev V, Wlcek K, Buchbauer G, Stoyanova A, Dobreva A, Schmidt E, Jirovetz L. Comparative evaluation of antimicrobial activity and composition of rose oils from various geographic origins, in particular Bulgarian rose oil. Nat Prod Commun. 2008;3:1063-8.

38. Kamatou GPP, Viljoen AM. Linalool-a review of a biologically active compound of commercial importance. Nat Prod Commun. 2008:3:1183-92.

39. Mahdian F, Mahboubi M, Rahimi E, Shad MM. Chemical composition, antimicrobial and antioxidant activities of Echinophora platyloba essential oil. Infectio. 2017;21:176-81.

40. Gogoi R, Loying R, Sarma N, Begum T, Lal SK. Comparative analysis of invitro biological activities of methyl Eugenol rich Cymbopogon khasianus hack. Leaf Essential Oil with Pure Methyl Eugenol Compound Curr Pharm Biotechno. 2020;21(10):927. https://doi.org/10.2174/ 1389201021666200217113921.

41. Van Vuuren S, Suliman S, Viljoen A. The antimicrobial activity of four commercial essential oils in combination with conventional antimicrobials. Lett Appl Microbiol. 2009:48:440-6.

42. Granata G, Stracquadanio S, Leonardi M, Napoli E, Consoli GML, Cafiso V, et al. Essential oils encapsulated in polymer-based nanocapsules as potential candidates for application in food preservation. Food Chem. 2018; 269:286-92

43. Pranchevicius MCS, Vieira TR. Production of recombinant immunotherapeutics for anticancer treatment: the role of bioengineering. Bioengineered. 2013;4:305-12.

44. Zhang Y, Liu X, Wang Y, Jiang P, Quek SY. Antibacterial activity and mechanism of cinnamon essential oil against E. coli and S. aureus. Food Control. 2016;59:282-9.

45. Heydari M, Zanfardino A, Taleei A, Shahnejat Bushehri A, Hadian J, Maresca $V$, et al. Effect of heat stress on yield, Monoterpene content and antibacterial activity of essential oils of Mentha x piperita var. Mitcham and Mentha arvensis var. piperascens. Molecules. 2018;23:1903.

46. Dalbey RE, Kuhn A. Protein traffic in gram-negative bacteria - how exported and secreted proteins find their way. FEMS Microbiol Rev. 2012;36:1023-45.

47. Arrigo D. M, Ginestra G, Mandalari G, Furneri P, Bisignano G. synergism and postantibiotic effect of tobramycin and Melaleuca alternifolia (tea tree) oil against S. aureus and E. coli. Phytomedicine. 2010;17:317-22.

\section{Publisher's Note}

Springer Nature remains neutral with regard to jurisdictional claims in published maps and institutional affiliations.

Ready to submit your research? Choose BMC and benefit from

- fast, convenient online submission

- thorough peer review by experienced researchers in your field

- rapid publication on acceptance

- support for research data, including large and complex data types

- gold Open Access which fosters wider collaboration and increased citations

- maximum visibility for your research: over $100 \mathrm{M}$ website views per year

At $\mathrm{BMC}$, research is always in progress.

Learn more biomedcentral.com/submissions 